\section{HANDBOOK OF POISONS}

By Robert H. Dreisbach, M.D., Ph.D. Pp. 426. Los Altos: Lange Medical Publications. 1956. $\$ 3.00$.

Only in format can this be considered a handbook, for within its modest compass lies more practical information about poisons and poisoning than can be found in most textbooks. One wonders at the omniscience of the author that has enabled every worthwhile detail of nearly every known poison (whether medicinal, agricultural or industrial) to be included. Most poisoning cases demand speedy diagnosis and treatment and a work of reference should be designed with this essential in mind; in the present volume the text is so displayed that no time will be lost in finding what immediate measures should be taken. The structural formula of the poison is first given, followed by the clinical findings, treatment, prophylaxis and prognosis. Each of these sub-headings contains just the information one needs and, perhaps, with the dogmatism so comforting in an emergency!

It is natural to turn to those pages dealing with poisons with which we are most often concerned and, in doing so, it is at once apparent how divergent views on treatment may be. In barbiturate coma the author holds no brief for the analeptic drugs and states that no antidote is known; no mention is made of the antipodean antidote bemegride (" Megimide'), which has been used with considerable success. Indeed, what does or does not constitute an antidote may have given the author some trouble; under ' anticoagulants' neither heparin nor the synthetics are accorded one, whereas I per cent. injection of protamine sulphate surely fills the bill for the former and natural vitamin $K_{1}$ for the latter. This monograph on anticoagulants is not quite satisfactory; the author fails to stress the importance of using vitamin $K_{1}$ and not one of the synthetic analogues which have been used in the past with such poor results. No mention at all is made of protamine sulphate, which removes circulating heparin.

But if it is the reviewer's job to find faults in a work, then this one has presented a difficult task. It is easier (and pleasurable) in this instance to give unqualified approval to a volume to which every casualty department certainly, and perhaps every general practitioner, ought to have ready access.

M.H.P.

\section{A FOLLOW-UP STUDY OF WAR NEUROSES V.A. Medical Monograph}

By Norman Q. Brill, M.A., and Gilbert W. Berbe, Ph.D. Pp. xviii +393 , with I I diagrams. Washington: Veterans Administration. 1955.

As the authors say in their introduction, comparatively little is known about the natural history of the neuroses. This book is the report of a follow-up study of neuroses occurring in time of war among the United States Forces; the studog was directed by the National Research Council ara financed by the Veterans Administration. The material for the study consisted of a representative sample of men admitted to the Forces in 194 985 from the Army and 490 from the Navy and Marine Corps. Of this total of 1,475 men, 955 . were examined by one of 225 psychiatrists throughs? out the country, and the rest studied on the basis of records only. Most of the psychiatric examinis tions were made in the fifth or sixth year after fir admission for psychoneurosis. Information in the examination and reports was converted into a form allowing of coding and statistical analysis.

The bulk of the book is made up of a detailed survey of this analysis, and it does not lend itseff to summarizing. A vast amount of information is contained in the many tables and chapters, and thy book is well and clearly set out. Part I is concerned with characteristics of the population sample\& Part II with an analysis of follow-up data, Part I with an analysis of military experience, Part IS with a survey of the pre-service period, and Part $\$ 5$ with the implications of this study for the utilization of manpower.

Perhaps the most interesting part of the book f $\overrightarrow{\propto V}$ the clinical worker is Chapter IV, on follow-u status. Ninety per cent. of the men examined complained of symptoms, especially irritabibity anxiety, gastro-intestinal complaints, restlessies and headache. In 14 per cent. full-time empdos ment seemed to be prevented by illness. STx per cent. of the men who had been ill at disch had improved by the time they appeared of or examination. Only 36 per cent. had sought Ganf treatment for their symptoms. Some 40 per cont were drawing compensation for psychiatric ability, but in only to per cent. of the entife sample was such payment thought to have an effect.

Medical literature contains few such large-scale studies of neurosis, and very few so well doce mented as this. The authors are to be congrat $\$$ lated on the product of their prolonged and diligent labour.

MANAGEMENT OF LIFE-THREATENING $\stackrel{3}{3}$. POLIOMYELITIS

Edited by H. C. A. Lassen, M.D. Pp. xix $+r 7 \%$ with 55 illustrations. Edinburgh: E. \& Livingstone Ltd. 1956. 22s. 6d.

This book contains a series of papers analysing the experiences gained in the 1952-53 poliomyelitis epidemic in Copenhagen. This epidemic w characterized by an unusually high percentage $\overline{\mathcal{R}}$ patients suffering from bulbar paralysis and the manner in which Professor Lassen and his colleagures tackled this emergency was a remarkable achieves ment. This factor and the limited number $\mathscr{E}$ mechanical respirators available soon led them treat almost all their patients who showed evidence 
of respiratory failure by tracheotomy and intermittent positive pressure respiration. There may be some disagreement over the frequency that this form of treatment should be used but there can be little doubt that it is life-saving in patients suffering from difficulty in swallowing as well as in breathing. The knowledge gained at Copenhagen has proved invaluable to other workers in this field and it is well presented in this book.

There are chapters on various aspects of the acute stage of the illness such as the performance of a tracheotomy and of bronchoscopy, the types of artificial ventilation available, the physiotherapy that should be given and the complications that may ensue. Problems that may arise when the patient has begun to recover are also dealt with. These include the removal of the tracheotomy tube and the weaning of the patient from artificial respiration. There are also chapters in such subjects as the laboratory control of gas exchange and the electrocardiographic changes in acute poliomyelitis. Finally there is a report on the autopsy findings.

This book can be recommended to anyone likely to be called upon to treat patients with poliomyelitis and they will find much that is of value in this record of the work of those who were faced with an almost unique epidemic.

N.S.G.

\section{DIAGNOSIS AND TREATMENT OF VASCULAR DISORDERS. ANGIOLOGY}

Edited by Saul S. SAMuel, A.M., M.D., F.A.C.A., F.A.C.C. Pp. ix +621 , with 367 illustrations. London: Bailliere, Tindall and Cox Ltd. 1956. I $28 \mathrm{~s}$.

This book is a survey by a group of authors drawn, for the most part, from the United States, but including Professor Boyd, of Manchester, and one of his associates. It is evident that the editor and his contributors have aimed to cover the whole field contained in the title, so that the book opens with chapters devoted to the anatomy and physiology of the peripheral vessels both in health and in states of disease. The chapter dealing with the examination of the patient covers a very wide range of methods of clinical and ancillary study, besides analysing the symptomatology encountered in these patients in some detail. The chapter on angiography, rather unexpectedly describing angiocardiography for good measure, is followed by the body of the book describing in turn the various disorders of the peripheral circulation, arterial, venous and lymphatic. The chapter dealing with arterial injuries covers the experience derived from. recent wars in detail and the resulting advances very well and this is so of the chapters covering the major vascular diseases.

However, the details of surgical treatment have been dismissed to other sources by the editor, so that the book is not so much intended for a surgeon as for reference purposes in a more general field. The extensive range of analysis of symptoms and of methods of study are, in fact, rather wider than a clinician is likely to require and it seems rather easy to become lost in the detail so generously supplied.

The actual format of the book cannot be criticized. In type, quality of paper and in the excellence of the illustrations the book is typical of this publisher's publications.

\section{MEDITATIONS ON MEDICINE AND} MEDICAL EDUCATION PAST AND PRESENT

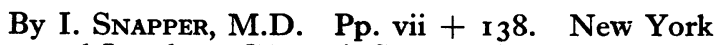
and London: Grune \& Stratton. 1956. \$3.75.

From an extensive review of medicine in the Netherlands in the $17^{\text {th }}$ and 18 th centuries the author, himself born and educated in Amsterdam, traces the influence of European ideas in the development of American medical schools and discusses the evolution of modern methods of teaching. Over a third of the book is devoted in great detail to the early colonists, which is perhaps out of proportion, but will appeal, as will the whole book, to those interested in the history of medicine.

\section{A.S.}

\section{LIFE OF SIR JOHN BLAND SUTTON}

By W. R. BETT, M.R.C.S. Pp. viii + Ioo, with 5 illustrations. Edinburgh: E. \& S. Livingstone Ltd. 1956. 20 .

A surgeon whose interests cover not only clinical and pathological research in his chosen profession, but take in almost the whole field of nature and range from astronomy to travel and authorshipe provides his biographer with an abundance of material of which Dr. Bett makes full use. The test is enlivened by descriptions of those unrehearsed incidents which throw so much light on the character of a man, and by well-chosen quotations from Bland Sutton's speeches and writings to illustrate his love of the striking phrase. One's interest is retained throughout this readable little book.

A.S.

\section{NEUROLOGY AND PSYCHIATRY IN CHILDHOOD}

Proceedings of the Association for Research I in Nervous and Mental Disease, Vol. XXXIV. Edited by R. McInTosh, M.D., and C. C. HARE, M.D. Pp. xii +504 , with 63 illustrations. London: Baillière, Tindall \& Cox Ltd. 1956. 88 s.

The annual research publications of the Association for Research into Nervous and Mental Disease will be well known to readers. This 34th volume maintains the high standard of its predecessors, and presents in 14 chapters a very broad spectrum of the neurological disorders in childhood. The chapters on the radiological features of 